\title{
Radium-226 and Radium-228 in Shallow Ground Water, Southern New Jersey
}

Concentrations of total radium (the sum of radium-226 and radium-228) and gross alpha-particle activities in drinking water that exceed the U.S. Environmental Protection Agency (USEPA) Maximum Contaminant Levels (MCLs) are known to cause cancer. Results of investigations by the U.S. Geological Survey (USGS) in cooperation with the New Jersey Department of Environmental Protection (NJDEP) indicate that concentrations of total radium in water samples from 33 percent of 170 wells in the Kirkwood-Cohansey aquifer system in southern New Jersey exceeded the MCL of $5 \mathrm{pCi} / \mathrm{L}$ (picocuries per liter) (fig. 1). Wells containing water in which concentrations of total radium were greater than the MCL typically are found where the Bridgeton Formation crops out, in or near an agricultural area, where ground water is acidic (pH less than 5), and where nitrate concentrations generally exceed $5 \mathrm{mg} / \mathrm{L}$ (milligrams per liter). Leaching of nitrogen, calcium, and magnesium from agricultural chemicals (fertilizer, lime) applied to cropland may increase the mobility of radium in ground water. Gross alphaparticle activities exceeded the USEPA MCL of $15 \mathrm{pCi} / \mathrm{L}$ in water from 14 percent of 127 wells. A statistically significant 2:1 ratio between gross alpha-particle activity and concentration of total radium indicates that gross alpha-particle activity can be used as a screening tool to predict the presence of water that may have a high total-radium concentration.
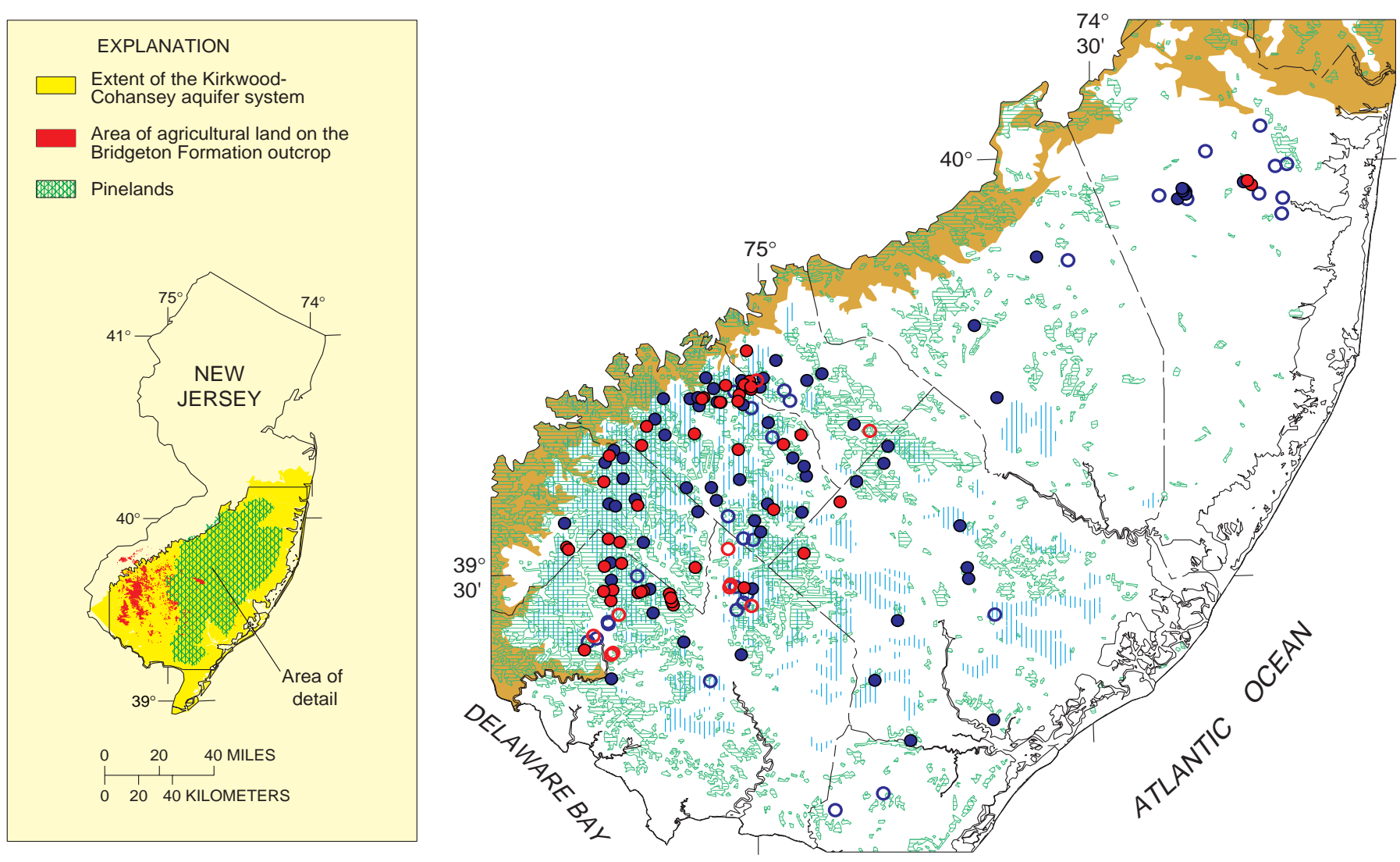

EXPLANATION

PUBLIC-SUPPLY WELLS

Kirkwood Formation outcrop

Cohansey Sand outcrop

Bridgeton Formation outcrop

Agricultural land
- Total radium concentration less than 5 picocuries per liter

- Total radium concentration greater than 5 picocuries per liter

\section{ALL OTHER WELLS}

- Total radium concentration less than 5 picocuries per liter

- Total radium concentration greater than 5 picocuries per liter

Figure 1. Extent of the Kirkwood-Cohansey aquifer system in New Jersey, areas of agricultural land use, and locations of wells sampled for analysis of radium concentrations, 1988-96. 


\section{What is radium and why is it present in water?}

Unstable radioactive elements are found in a wide range of concentrations in all rocks, soil, and water. The most common radioactive elements, uranium and thorium, decay slowly and produce other radioactive elements, such as radium, which in turn undergo still further radioactive decay. These radioactive product elements have different chemical properties, decay at different rates, and emit different levels of radiation energy than either uranium or thorium.

The two most common isotopes of radium are radium226 and radium-228. Radium-226 has a long half-life $(1,600$ years) compared to that of radium-228 (5.75 years). A half-life is the time required for half of the initial amount of the radionuclide to decay. Radium-226 decays by emitting the nucleus of a helium atom (alpha particle), whereas radium-228 emits an electron (beta particle).

Radium is only moderately soluble in water and only under certain geochemical conditions (Zapecza and Szabo, 1988); radium-226 and radium-228 are equally soluble. Radium can enter ground water by dissolution of aquifer materials, by desorption from rock or sediment surfaces, and by ejection from minerals during radioactive decay.

\section{Why is radium in drinking water of concern?}

Radium in drinking water is known to increase cancer risk, primarily for bone and sinus cancers (Mays and others, 1985). As radium decays, the radiation that is emitted can strip electrons from the atoms with which it collides, causing the atoms to become charged or "ionized." The ionizing alpha and beta radiation emitted by radium consists of particles that move slowly and cannot penetrate skin. If radium is ingested, however, especially dissolved in water, the emitted alpha- and beta-particle radiation can ionize and damage cell tissue. Human bone tissue accumulates radium rather than allowing it to be removed from the body, thereby exposing the bones to tissue-damaging alpha or beta radiation. Damage from continuous exposure can potentially cause cancer. Because it accumulates in the body, radium is considered to pose a greater cancer risk than most other radioactive elements.

\section{What level of radium or gross alpha-particle activity in drinking water is a significant health risk?}

The USEPA MCL for radioactivity in drinking water is set at the level of a 1 in 10,000 risk of a fatal cancer if 2 liters of water per day is consumed for 70 years. The MCL for the concentration of total dissolved radium, which is defined as the sum of radium-226 and radium-228 concentrations, is $5 \mathrm{pCi} / \mathrm{L}$ (U.S. Environmental Protection Agency, 1976). For gross alphaparticle activity, the USEPA MCL is $15 \mathrm{pCi} / \mathrm{L}$ (U.S. Environmental Protection Agency, 1976). Activity is the number of radioactive disintegrations in a given quantity of material per unit time. Gross alpha-particle activity is a measure of the total amount of radioactivity in a water sample attributable to the radioactive decay of alpha-emitting radioactive elements. Activity in water is expressed in units of picocuries per liter, where $1 \mathrm{pCi} / \mathrm{L}$ is equal to 2.2 radioactive disintegrations per minute per liter of water. Because radium-226 emits an alpha particle, gross alpha-particle activity can be used as a screening tool to predict the presence of radium in a water sample, if large amounts of other alphaemitting radioactive elements are absent.

\section{Radium in ground water in southern New Jersey}

During routine regulatory monitoring conducted by the NJDEP, naturally occurring radium was detected at concentrations greater than the MCL in water from public supply wells screened in the Kirkwood-Cohansey aquifer system. From 1988 to 1996, the USGS, in cooperation with the NJDEP, conducted several sampling programs to determine the distribution of total dissolved radium in the aquifer system and to identify factors that contribute to the presence of high concentrations of total dissolved radium.

The Kirkwood-Cohansey aquifer system is a regionally extensive unconfined (water-table) aquifer that underlies about two-thirds of the New Jersey Coastal Plain (fig. 1). It is a major source of drinking water in much of southern New Jersey. In most areas, the aquifer consists of two geologic formations, the Cohansey Sand and the Kirkwood Formation. The Cohansey Sand is mainly a light-colored, medium- to coarse-grained quartz sand with some gravel and silt (Zapecza, 1989). The Kirkwood Formation is a fine- to medium-grained quartz and silty sand in inland areas and grades to clay in coastal areas. A surficial deposit of feldspathic gravel known as the Bridgeton Formation discontinuously overlies the Cohansey Sand and, in places, the Kirkwood Formation on topographic highs, especially in southwestern New Jersey. These three hydraulically connected units form the aquifer system, although the Bridgeton Formation is present primarily in recharge areas. The Bridgeton Formation contains a greater concentration of natural radioactive elements than the other two formations because it was deposited by the ancestral Hudson River (Martino, 1981), which drained rocks to the north that were enriched in radioactive minerals relative to the source material for the Kirkwood Formation and the Cohansey Sand.

Table 1. Summary statistics for radium concentrations and gross alpha-particle activity in water from wells in the Kirkwood-Cohansey aquifer system, southern New Jersey, 1988-96 [USEPA, U.S. Environmental Protection Agency; MCL, Maximum Contaminant Level]

\begin{tabular}{|c|c|c|c|c|c|c|c|}
\hline \multirow[b]{2}{*}{ Dissolved constituent } & \multirow{2}{*}{$\begin{array}{l}\text { USEPA } \\
\text { MCL } \\
\text { (picocuries } \\
\text { per liter) }\end{array}$} & \multirow{2}{*}{$\begin{array}{l}\text { Potential health effects } \\
\text { from ingestion of water } \\
\text { (Mays and others, 1985) }\end{array}$} & \multirow{2}{*}{$\begin{array}{c}\text { Number } \\
\text { of wells } \\
\text { sampled }\end{array}$} & \multicolumn{3}{|c|}{$\begin{array}{l}\text { Concentration or activity } \\
\text { (picocuries per liter) }\end{array}$} & \multirow{2}{*}{$\begin{array}{c}\text { Percentage of samples } \\
\text { with concentration or } \\
\text { activity above the } \\
\text { MCL }\end{array}$} \\
\hline & & & & Minimum & Maximum & Median & \\
\hline $\begin{array}{l}\text { Total radium } \\
\text { (radium-226 plus radium-228) }\end{array}$ & 5 & Bone cancer & 170 & $<1$ & 30.3 & 3.8 & 33 \\
\hline Gross alpha-particle activity & 15 & Cancer & 127 & $<0.6$ & 43.3 & 5.4 & 14 \\
\hline
\end{tabular}




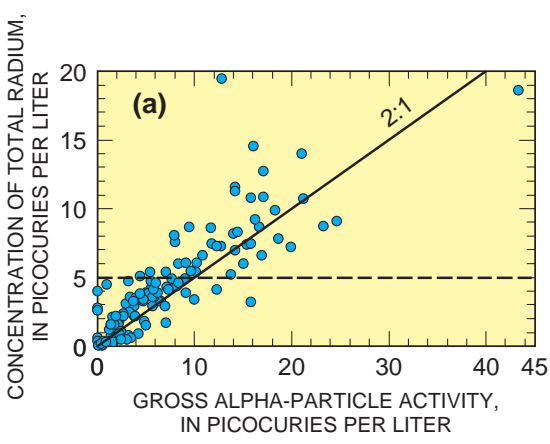

IN PICOCURIES PER LITER

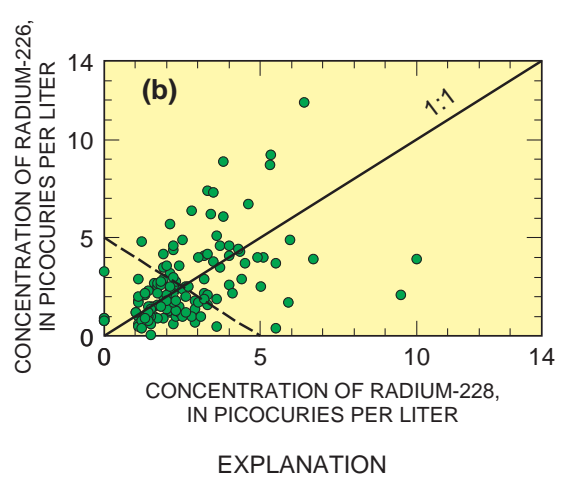

EXPLANATION

Maximum Contaminant Level for
total radium (5 picocuries per liter)

Concentration of nitrate plus nitrite

5 milligrams per liter

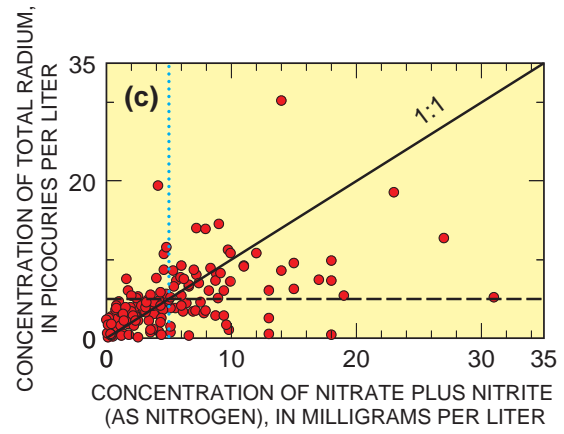

Figure 2. (a) Concentration of total radium as a function of gross alpha-particle activity; (b) concentration of radium-226 as a function of concentration of radium-228; and (c) concentration of total radium as a function of nitrate plus nitrite concentration in water from wells in the Kirkwood-Cohansey aquifer system, southern New Jersey, 1988-96.

\section{Sampling Program}

The USGS sampled a regional network of 170 wells, including public-supply, domestic, and observation wells, to characterize the distribution of total dissolved radium in the Kirkwood-Cohansey aquifer system in southern New Jersey (Kozinski and others, 1995; Szabo and others, 1997). Samples were analyzed for radium concentration and for gross alphaparticle activity by using USEPA-approved techniques (Krieger and Whitaker, 1980) about 1 month after collection. Sampling density was greatest in the southwestern part of the study area (fig. 1) because of the large rural and suburban population that depends solely on water from the Kirkwood-Cohansey aquifer system for water supply, and because concentrations of total dissolved radium were highest in this area. Sampling density was lowest in the central part of the study area (the Pinelands; fig. 1) because of the absence of residences (and wells) in this area. Because sampled wells were not distributed evenly throughout the study area, the data set of measured total dissolved radium concentrations may be biased.

\section{Radium concentrations in ground water}

The concentration of total radium in water from 56 (33 percent) of the 170 wells sampled was greater than the $5-\mathrm{pCi} / \mathrm{L}$ MCL (table 1). Concentrations of total dissolved radium ranged from $<1.1$ to $30.3 \mathrm{pCi} / \mathrm{L}$, with a median (midpoint value) of 3.8 $\mathrm{pCi} / \mathrm{L}$. Gross alpha-particle activities in 18 (14 percent) of the 127 samples for which data were available were greater than the $15-\mathrm{pCi} / \mathrm{L}$ MCL. Gross alpha-particle activities ranged from $<0.6$ to $43.3 \mathrm{pCi} / \mathrm{L}$, with a median of $5.4 \mathrm{pCi} / \mathrm{L}$. Gross alpha-particle activity and total radium concentration were significantly (95percent or greater statistical confidence interval) correlated (Spearman rank correlation coefficient, $r_{S}=+0.90$ ); the ratio typically was about 2:1 (fig. 2a). Concentrations of radium-226 and radium-228 also were significantly correlated $\left(r_{s}=+0.70\right)$. The median ratio of the concentrations of radium-228 to radium226 was 1.06 (fig. 2b). This ratio indicates that radioactive minerals in the sands that make up the aquifer system are the likely source of the dissolved radium because they also contain both radioisotopes in nearly equal proportions (Szabo and others,
1997), whereas likely anthropogenic sources of radium, such as phosphate-bearing fertilizers, tend to contain much more radium226 than radium-228.

\section{Relation of radium to other chemical constituents}

Results of a rank-order-regression statistical model indicate that water from the Kirkwood-Cohansey aquifer system in which the nitrate concentration was greater than $5 \mathrm{mg} / \mathrm{L}$ typically contained total radium in concentrations greater than $5 \mathrm{pCi} / \mathrm{L}$ (fig. 2c). Of 63 samples with a nitrate concentration greater than $5.0 \mathrm{mg} / \mathrm{L}, 41$ ( 65 percent) had total radium concentrations greater than $5.0 \mathrm{pCi} / \mathrm{L}$. In contrast, of 92 samples with a nitrate concentration less than $5.0 \mathrm{mg} / \mathrm{L}$, only 14 (15 percent) had total radium concentrations greater than $5.0 \mathrm{pCi} / \mathrm{L}$. Of 75 samples with a dissolved-magnesium concentration greater than or equal

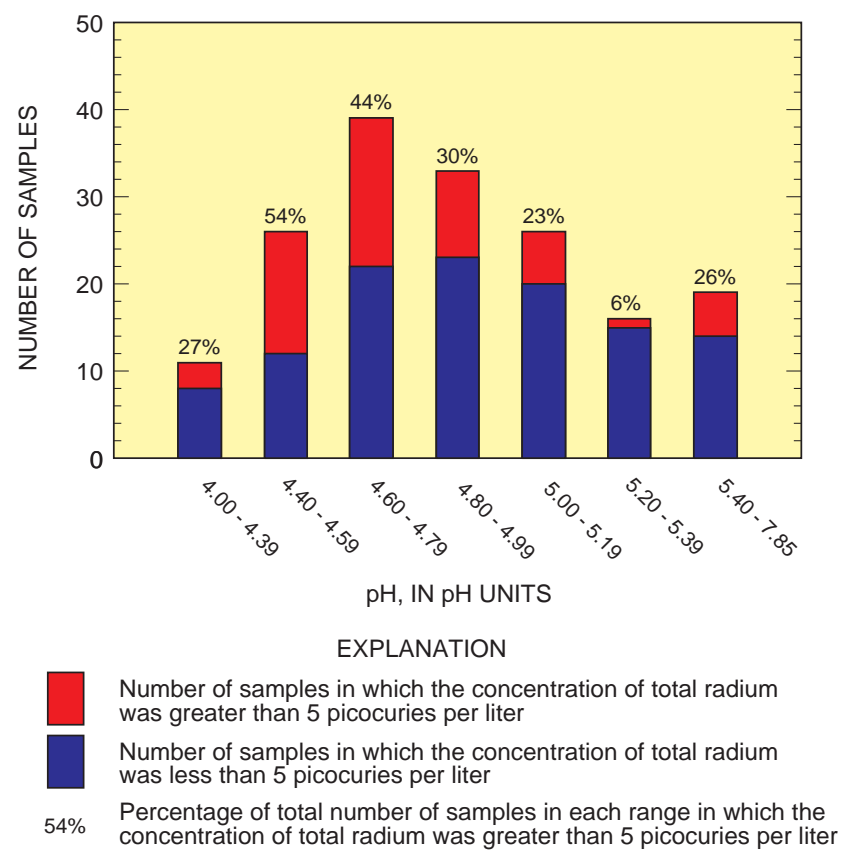

Figure 3. Number of water samples in which the concentration of total radium exceeded 5 picocuries per liter as a function of $\mathrm{pH}$, Kirkwood-Cohansey aquifer system, southern New Jersey, 1988-96. 


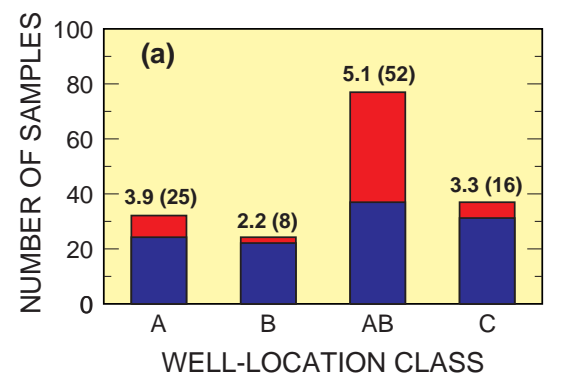

A Samples from wells in
agricultural area
EXPLANATION

Total radium concentration $>5$ picocuries per liter Total radium concentration $<5$ picocuries per liter

5.1 Median total radium concentration in picocuries per liter

(52) Percentage of samples in which total radium concentration $>5$ picocuries per liter

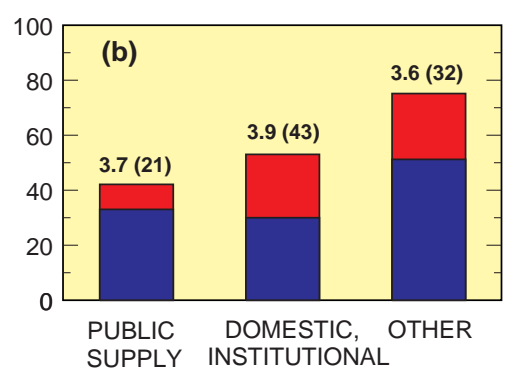

$\mathrm{AB} \quad$ Samples from wells in agricultural and in Bridgeton Formation outcrop area

C Samples from wells in neither agricultura nor Bridgeton Formation outcrop area

Figure 4. Percentage of water samples in which total radium concentration exceeded the Maximum Contaminant Level by (a) welllocation class and (b) well type, Kirkwood-Cohansey aquifer system, southern New Jersey, 1988-96.

to $3 \mathrm{mg} / \mathrm{L}, 47$ (63 percent) had total radium concentrations greater than $5 \mathrm{pCi} / \mathrm{L}$. Of 95 samples with a dissolved-magnesium concentration less than $3 \mathrm{mg} / \mathrm{L}$, total radium concentrations in only 9 ( 9 percent) exceeded the MCL of $5 \mathrm{pCi} / \mathrm{L}$. Concentrations of total radium greater than $5 \mathrm{pCi} / \mathrm{L}$ also were related to low $\mathrm{pH}$ (acidic water). Of the 56 water samples in which the concentration of total radium exceeded $5 \mathrm{pCi} / \mathrm{L}, 34$ (61 percent) had a $\mathrm{pH}$ $<4.8$ (fig. 3). Statistically significant Spearman rank correlation coefficients for concentrations of total dissolved radium relative to those of nitrate and magnesium were +0.65 and +0.64 , respectively. Although concentrations of total radium also were correlated with those of other dissolved constituents, these relations were less strong (Kozinski and others, 1995).

\section{Relation of radium concentration to agricultural land use and geology}

Radium concentration and gross alpha-particle activity, as well as concentrations of nitrate and magnesium, were highest in water from wells in agricultural areas overlying the outcrop of the Bridgeton Formation. Of the 56 water samples in which the concentration of total radium exceeded $5 \mathrm{pCi} / \mathrm{L}, 40$ (71 percent) were from wells in areas of both agricultural land use and the Bridgeton Formation outcrop. Of the 19 samples in which gross alpha-particle activity was greater than $15 \mathrm{pCi} / \mathrm{L}, 15$ (79 percent) were collected from wells in agricultural areas overlying the outcrop of the Bridgeton Formation.
More than half the samples from wells in agricultural areas overlying the Bridgeton Formation outcrop contained total radium in concentrations exceeding the MCL (fig. 4). The median total dissolved radium concentration for these samples was $5.1 \mathrm{pCi} / \mathrm{L}$. The median concentration of total radium in water from wells in all non-agricultural land-use categories combined was less than $5 \mathrm{pCi} / \mathrm{L}$, and concentrations in only a small percentage of these samples exceeded the MCL.

\section{Relation of radium concentration to well depth}

To evaluate the distribution of total radium with depth and its relation to the distribution of water chemistry and tritium with depth in the aquifer system, water samples collected from 15 nested observation wells at five sites were analyzed for radium226, radium-228, gross alpha-particle activity, tritium, and major ions. Because the Kirkwood-Cohansey aquifer system consists mainly of quartz sand that, for the most part, does not react with water, the quality of the ground water is controlled primarily by the quality of the recharge water at the time it entered the aquifer. Tritium concentrations can be used to estimate the date of recharge of young ground water because tritium concentrations in the atmosphere were highest in the early 1960's as a result of above-ground testing of nuclear devices.

Concentrations of radium and gross alpha-particle activities were highly variable with depth but were consistently lowest in the deepest wells. Concentrations of total radium in water from

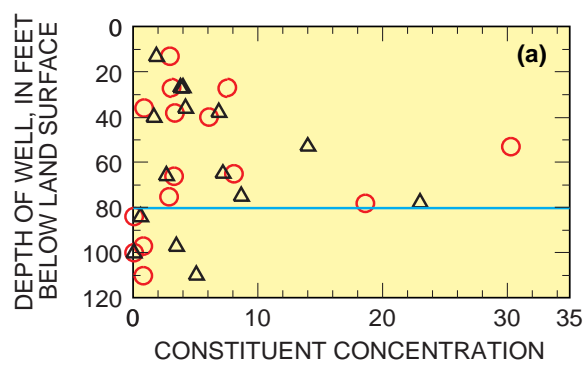

O

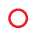

Concentration of total radium, in picocuries per liter

$\Delta$ Concentration of $\mathrm{NO}_{2}+\mathrm{NO}_{3}$, in milligrams per liter as $\mathrm{N}$

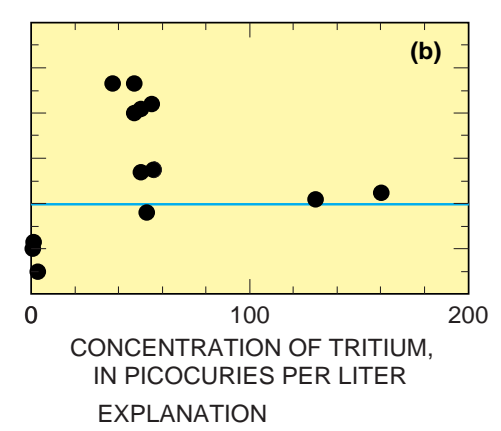

Approximate depth of ground water recharged in about 1963

Figure 5. (a) Concentration of total radium and nitrite plus nitrate $\left(\mathrm{NO}_{2}+\mathrm{NO}_{3}\right)$, (b) concentration of tritium, and (c) pH as a function of depth in samples of water from nested observation wells in the Kirkwood-Cohansey aquifer system, southern New Jersey, 1991. 
Table 2. Well type and median depth to open interval, percentage of wells located in agricultural areas, and median nitrate concentration in water from wells in the Kirkwood-Cohansey aquifer system, southern New Jersey, 1988-96 [mg/L, milligrams per liter]

\begin{tabular}{|l|c|c|c|}
\hline \multicolumn{1}{|c}{} & \multicolumn{1}{|c}{$\begin{array}{c}\text { Median depth to } \\
\text { top of well screen } \\
\text { Weet below land }\end{array}$} & $\begin{array}{c}\text { Percentage of } \\
\text { wells located in } \\
\text { agricultural } \\
\text { areas }\end{array}$ & $\begin{array}{c}\text { Median concen- } \\
\text { tration of ni- } \\
\text { trate plus nitrite } \\
\text { (mg/L) }\end{array}$ \\
\hline Public-supply & 93 & 38 & 2.8 \\
\hline $\begin{array}{l}\text { Domestic, } \\
\text { institutional }\end{array}$ & 63 & 81 & 5.95 \\
\hline Other & 50 & 67 & 3.8 \\
\hline
\end{tabular}

depths greater than about 80 feet below land surface were less than $1.75 \mathrm{pCi} / \mathrm{L}$ (fig. 5a). Corresponding tritium values of less than $10 \mathrm{pCi} / \mathrm{L}$ at depths greater than 80 feet indicate that the water was recharged more than 35 years ago (fig. 5b), and therefore, probably predates the intensive use of modern agricultural chemicals, such as nitrogen-bearing fertilizers. Consequently, nitrate concentrations at depths greater than 80 feet were equal to or less than $5 \mathrm{mg} / \mathrm{L}$ (fig. $5 \mathrm{a}$ ).

Water from shallow and medium depths (10-75 feet below land surface) generally contained higher concentrations of total radium (maximum, $30 \mathrm{pCi} / \mathrm{L}$ ) than water from the deep wells (maximum, $<1.75 \mathrm{pCi} / \mathrm{L}$ ). Tritium concentrations greater than

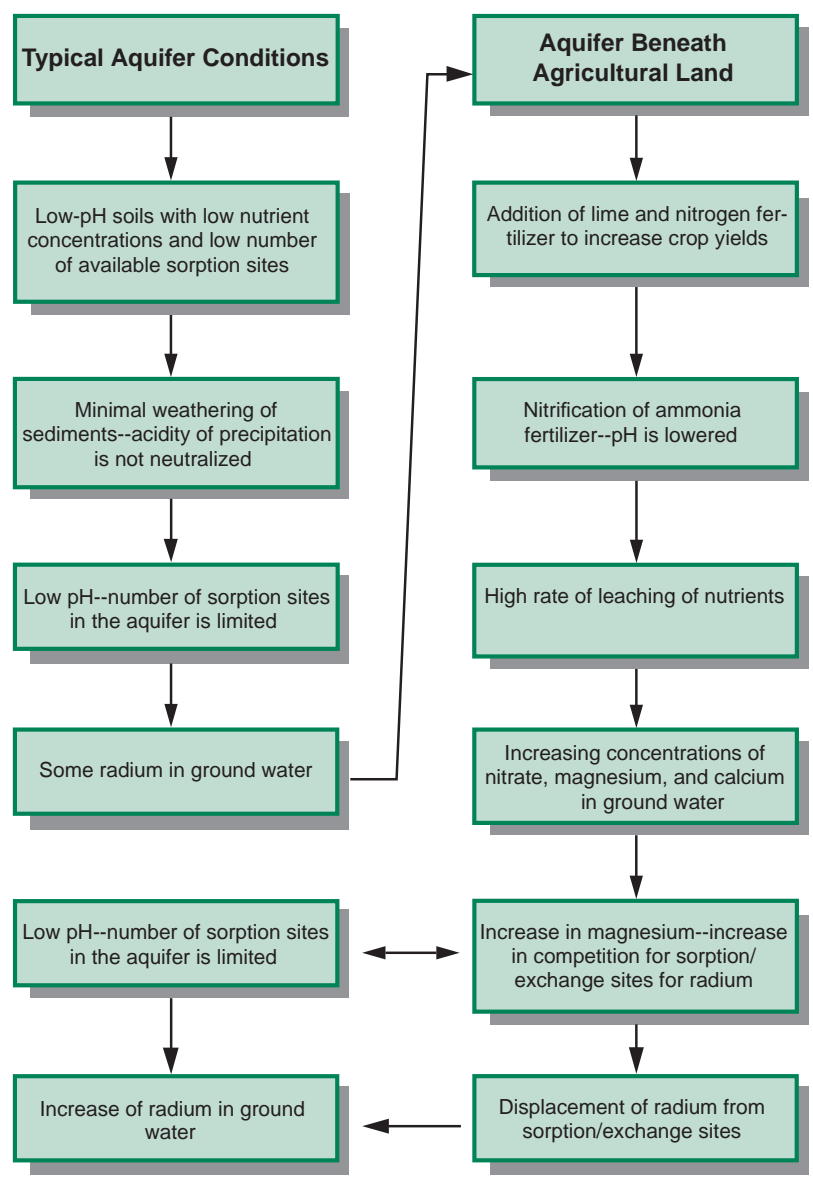

Figure 6. Processes that result in elevated concentrations of nitrate, magnesium, and radium in water in areas where agricultural land overlies the Kirkwood-Cohansey aquifer system, southern New Jersey. (Modified from Szabo and others, 1997)
$100 \mathrm{pCi} / \mathrm{L}$ at depths of about 80 feet below land surface correspond to the depth of penetration into the aquifer system of water recharged in the early 1960's. Tritium concentrations to about 75 feet below land surface generally were about $50 \mathrm{pCi} / \mathrm{L}$, indicating that the water was recharged less than about 30 years ago, during a period of intensive use of modern agricultural chemicals.

Consequently, most nitrate concentrations at shallow and medium depths were greater than $5 \mathrm{mg} / \mathrm{L}$ (fig. $5 \mathrm{a}$ ).

The $\mathrm{pH}$ of water from the nested wells increased with depth (fig. 5c). The $\mathrm{pH}$ of the shallow ground water is low as a result of acidic precipitation and the biological transformation of nitrogen-bearing fertilizers. As recharge penetrates the aquifer system, the water is slowly neutralized by the chemical reactions of natural weathering, such as the dissolution of feldspar from sand grains, and the solubility of radium decreases. The increase in $\mathrm{pH}$ with depth corresponds roughly with the decrease in the concentrations of dissolved radium and nitrate; these chemical relations are similar to those observed in water from wells in the regional well network (fig. 3).

Although total radium concentrations were greatest in water from medium depths, radium in the aquifer sediments is not enriched at the depths at which these wells are screened (Szabo and others, 1997). These results indicate that the chemistry of the water rather than the radium content of the sediment is primarily responsible for the high concentrations of radium. The flow diagram in figure 6 illustrates the effects of both natural water quality and water quality altered by the addition of agricultural chemicals on the mobility of radium in the Kirkwood-Cohansey aquifer system, and identifies mechanisms that may increase radium mobility in shallow ground water in agricultural areas.

\section{Relation of radium to well type}

The MCL for total radium was exceeded less frequently in water from public-supply wells than in water from domestic or other types of wells (fig. 4), possibly because public-supply wells typically are distant from agricultural areas and generally are associated with lower nitrate concentrations, greater pumping rates, and substantially deeper intakes than other well types (table 2 ). Because public-supply wells discharge large volumes of water, they typically withdraw and integrate water from different land-use areas and depths, resulting in a measured total radium concentration that is lower than the highest concentration within a small depth interval in the aquifer near the well. The frequent detection of high radium concentrations in domestic and institutional wells may be due to their location in agricultural areas, their location where nitrate concentrations are high, and their typically short, medium-depth screens, which intercept young, radium-rich water without appreciable dilution.

\section{Summary and Discussion}

Ground water containing total radium in concentrations greater than the 5-pCi/L MCL is widespread (33 percent of 170 samples) in the Kirkwood-Cohansey aquifer system in southern New Jersey. Gross alpha-particle activity exceeded the $15-\mathrm{pCi} / \mathrm{L}$ MCL in a significant number of samples (14 percent of 127 samples). Concentrations of total radium greater than $5 \mathrm{pCi} / \mathrm{L}$ are 
most likely to be present in shallow to moderately deep (as much as 80 feet below land surface) ground water that has been recharged since the early 1960's (the time of greatest fertilizer application), is acidic ( $\mathrm{pH}<5)$, is located on the Bridgeton Formation outcrop and in areas of current or historical agricultural land use, and has been contaminated with nitrate to concentrations of about $5 \mathrm{mg} / \mathrm{L}$ or more.

Public-supply utilities and homeowners whose wells are screened in the Kirkwood-Cohansey aquifer system and meet any of the above criteria need to test their water for the presence of radium and gross alpha-particle activity (New Jersey Department of Environmental Protection, 1997). Because gross alpha-particle activity is significantly correlated to total radium concentration, it can be used as a cost-effective screening tool. Analysis of water for gross alpha-particle activity is much less costly than analysis for radium; therefore, a homeowner whose well produces water containing gross alpha-particle activity greater than $5 \mathrm{pCi} / \mathrm{L}$ can save the expense of additional analytical costs and simply treat the water for radium (New Jersey Department of Environmental Protection, 1997). Drinking water from public-supply systems can be treated, or other options, such as blending, can be pursued, to ensure limited exposure of consumers to radiation. Many treatments that can effectively reduce the concentration of radium and gross alpha-particle activity (New Jersey Department of Environmental Protection, 1997) are available to homeowners. Other options, such as drilling a deep well, using bottled water, or connecting to a public-supply utility, also are available. Information about all of these options can be obtained from the local health department or the NJDEP Bureau of Safe Drinking Water.

Investigations by the USGS are ongoing to evaluate the distribution of other radium isotopes in the Kirkwood-Cohansey aquifer system in New Jersey and their contribution to the gross alpha-particle activity in the water supply. Results of these studies will improve the understanding of the potential health risks to water consumers from radioactivity.

—Zoltan Szabo and Vincent dePaul

\section{References Cited}

Kozinski, Jane, Szabo, Zoltan, Zapecza, O.S., and Barringer, T.H., 1995, Natural radioactivity in, and inorganic chemistry of, ground water in the Kirkwood-Cohansey aquifer system, southern New Jersey, 1983-89: U.S. Geological Survey WaterResources Investigations Report 92-4144, 130 p.

Krieger, H. L., and Whitaker, E.L, 1980, Prescribed procedures for measurement of radioactivity in drinking water: U.S. Environmental Protection Agency Manual EPA-600/4-80-032, $111 \mathrm{p}$.

Martino, R.L., 1981, The sedimentology of the late Tertiary Bridgeton and Pensauken Formations in southern New Jersey: New Brunswick, N.J., Rutgers University, unpublished Ph.D. dissertation, 299 p.

Mays, C.W., Rowland, R.E., and Stehney, A.F., 1985, Cancer risk from the lifetime intake of $\mathrm{Ra}$ and $\mathrm{U}$ isotopes: Health Physics, v. 48 , p. $635-647$.
New Jersey Department of Environmental Protection, 1997, A homeowner's guide to radioactivity in drinking water: Trenton, N.J., New Jersey Department of Environmental Protection, Bureau of Safe Drinking Water, June 1997, 4 p.

Szabo, Zoltan, Rice, D. E., McLeod, C.L., and Barringer, T.H., 1997, Relation of distribution of radium, nitrate, and pesticides to agricultural land use and depth, Kirkwood-Cohansey aquifer system, New Jersey Coastal Plain, 1990-91: U.S. Geological Survey Water-Resources Investigations Report 96-4165A, 107 p.

U.S. Environmental Protection Agency, 1976, National primary drinking-water regulations: Washington, D.C., Office of Water Supply, U.S. Environmental Protection Agency Report EPA-570/9-76-003.

Zapecza, O.S., 1989, Hydrogeologic framework of the New Jersey Coastal Plain: U.S. Geological Survey Professional Paper 1404-B, 49 p., 24 pl.

Zapecza, O.S., and Szabo, Zoltan, 1988, Natural radioactivity in ground water-A review, in Moody, D.W., Chase, E.B., and Paulson, R.W., comp., National Water Summary 1986Ground-water quality: Hydrologic conditions and events: U.S. Geological Survey Water-Supply Paper 2325, p. 50-57.

For additional information contact: District Chief U.S. Geological Survey 810 Bear Tavern Road, Suite 206 West Trenton, New Jersey 08628 email: dc_nj@usgs.gov 